\title{
Legal Conditions and Data Provision for Land Property Exchange in the Processes of Land Consolidation and Land Compensation in Bulgaria ${ }^{2}$
}

Abstract: Land consolidation and land compensation require the evaluation of the pro-
ductivity of the exchanged or recompensed areas. A serious deficiency in land
consolidation regulations set by the Agricultural Land Ownership and Use
Act, 1991 is the $10 \%$ restriction on the difference in the exchanged areas before
and after land consolidation. The simultaneous action of the current method-
ology for equating lands by their quality, together with the legal restrictions
of this Act, limits the implementation of land consolidation to only highly
productive lands of the $1^{\text {st }}$ to the $3^{\text {rd }}$ land category. The objective of this paper
is to suggest a method for extending the implementation of land consolida-
tion to larger areas and to recommend a fairer calculation method in equating
lands by their quality. Two approaches to landed property exchange are unit-
ed. One of them is based on the mean estimates of land productivity per land
category (MLPE) (considering the Bulgarian Land Categorization System), the
other one - on the detailed land productivity estimates of each landed prop-
erty (DLPE). The adapted FAO Land Suitability Classification is suggested to
identify areas suitable for land consolidation. Regression analysis and expert
assessment were used. The data required for GIS processing are specified and
systemized. A proposal for the improvement of the legal framework is given.

Keywords: land consolidation, legislation, land quality, equalizing coefficients, GIS

Received: 1 March 2020; accepted: 16 March 2020

(C) 2020 Author. This is an open access publication, which can be used, distributed and reproduced in any medium according to the Creative Commons CC-BY 4.0 License.

1 University of Architecture, Civil Engineering and Geodesy, Sofia, Bulgaria, email: mdmoteva@gmail.com ORCID ID: https://orcid.org/0000-0002-9861-2966

2 UACEG Center for Research and Design (Project BN 209/18 “Guidelines for Agricultural Land Design") 


\section{Introduction}

Land consolidation in Bulgaria ceased in the middle of the last century with the establishment of the state-planned economy. The sole Cadaster and Land Consolidation Act in Bulgarian history was promulgated in 1941. In this Act, the main stage of the land consolidation process was regulated as "Estimation of agricultural land suitability and land valuation" (Art 42 of [1]). This Act was denominated in 1950 and the era of agricultural collectivization began. Nowadays, land consolidation is regulated by Art 37e of [2] and Chapter Nine of [3].

The main points are that:

1) Land consolidation is possible if an agreement among the owners, who own at least $10 \%$ of the arable land, has been signed (Art 373 paragraph 1 of [2]).

2) The state provides only methodological and technical assistance (Art 84, paragraph 2 of [3]).

3) The cost of creating consolidated properties is at the expense of the owners (Art 37e, paragraph 8 of [2]). There is an exception when consolidation is required for other reasons, e.g. construction of technical infrastructure.

4) State and municipal agricultural land may be included in the land consolidation plan, provided that the average size of the state and municipal land assets increases by at least $20 \%$ (Art 373, paragraph 1 of [2]).

5) The new owners of former state and municipal land are not allowed to dispose of that land acquired in this procedure for 10 years, including changing its main purpose of use (Art 36, paragraph 6 of [3]). This can be considered a preventive measure against further fragmentation.

The legal text that provoked this study is that of Art 88, paragraph 1 of [3]: a deviation less than $10 \%$ between the landed properties before and after the consolidation is allowed if not otherwise agreed. This text is a prerequisite for limiting the implementation of land consolidation and unfair land property exchange.

Problems with land consolidation and land exchange occur in many countries, for example: Czech Republic [4], Hungary [5], Poland [6-8], Turkey [9], The Netherlands [10] and Bulgaria [11-15]. Equalization of land areas from the point of view of their quality for production is done by traditional equalizing coefficients, which represent ratios of Land Productivity Estimates (LPE), which in turn are calculated after the Methodology for Work on Cadaster of Agricultural Land in PR Bulgaria [16].

Recently, [12] and [13] suggested an approach to equating land, also using the LPE but achieving more accurate results.

The objective of this paper is to suggest a way to extend land consolidation implementation in compliance with the Law, based on two approaches for equating lands. Concomitant objectives are to identify and systemize data for GIS processing of land consolidation and land compensation and to give proposals for the improvement of the legal framework on land consolidation. 


\section{Material and Methods}

The analysis uses data from the traditional Methodology for Work on the Agricultural Land Cadaster in PR Bulgaria [16], FAO Framework for Land Valuation [17], and an adapted to Bulgarian land categorization FAO Land Capability Classification [17]. The methodologies of [12] and [16] were compared in terms of their adequacy to Art 88, paragraph 1 of [3]. The range of their legal applicability was determined. The traditional Methodology [16] evaluates land through Detailed Land Productivity Estimates (DLPE) in a 100-DLPE scale, considering the natural characteristics of the site: soil quality and environmental impact. The National Land Categorization, regulated by [18], contains 10 land categories per each 10 consecutive DLPE. In [16], every two categories are united into one land class characterizing its suitability for crop growing: in total, 5 classes. The highest quality land $\left(1^{\text {st }}\right.$ category, land of very good quality) is estimated by $90-100$ DLPE and the worst $\left(10^{\text {th }}\right.$ category, unsuitable land) - as 1-10 DLPE (Tab. 1).

Table 1. Land classes in Bulgaria, based on land category

\begin{tabular}{||l|c|c||}
\hline Land classes by Petrov et al. 1988 [16] & Land category & DLPE (marginal values) \\
\hline \hline \multirow{2}{*}{ First (land of very good quality) } & 1 & $91-100$ \\
\cline { 2 - 3 } & 2 & $81-90$ \\
\hline \multirow{2}{*}{ Second (land of good quality) } & 3 & $71-80$ \\
\hline \multirow{2}{*}{ Third (land of medium good quality) } & 4 & $61-70$ \\
\cline { 2 - 3 } & 5 & $51-60$ \\
\hline \multirow{2}{*}{ Forth (land of bad quality) } & 6 & $41-50$ \\
\hline \multirow{2}{*}{ Fifth (unsuitable land) } & 7 & $31-40$ \\
\cline { 2 - 3 } & 8 & $21-30$ \\
\cline { 2 - 3 } & 9 & $11-20$ \\
\hline
\end{tabular}

Source: [16]

The traditional equalizing coefficients are calculated as ratios of the Mean values of the LPE (MLPE) for each land category (Tab. 2) [19]. They vary from 0.053 to 19.000. In the process of the restoration of the ownership of agricultural land, equalization was carried out according to Table 2 over its entire range. The errors that cause deviations from the market value and the integral productivity of the obtained properties occur as a result of two sources: 1) the first source, and which cannot be avoided, is the soil mapping scale in Bulgaria of 1:10,000; 2) the second one is hidden in the coefficients themselves, being calculated on a mean basis. 
Table 2. Popular scale for comparability of agricultural land of different categories, using mean land productivity estimates (MLPE)

\begin{tabular}{|c|c|c|c|c|c|c|c|c|c|c|c||}
\hline \multirow{2}{*}{$\begin{array}{c}\text { Soil } \\
\text { category }\end{array}$} & \multicolumn{10}{|c|}{ Soil category } & \multirow{2}{*}{ Average } \\
\cline { 2 - 13 } & 1 & 2 & 3 & 4 & 5 & 6 & 7 & 8 & 9 & 10 & \\
\hline \hline 1 & 1.000 & 1.118 & 1.267 & 1.462 & 1.727 & 2.111 & 2.714 & 3.800 & 6.333 & 19.000 & 95 \\
\hline 2 & 0.895 & 1.000 & 1.133 & 1.308 & 1.545 & 1.889 & 2.429 & 3.400 & 5.667 & 17.000 & 85 \\
\hline 3 & 0.789 & 0.882 & 1.000 & 1.154 & 1.364 & 1.667 & 2.143 & 3.000 & 5.000 & 15.000 & 75 \\
\hline 4 & 0.684 & 0.765 & 0.867 & 1.000 & 1.182 & 1.444 & 1.857 & 2.600 & 4.333 & 13.000 & 65 \\
\hline 5 & 0.579 & 0.647 & 0.733 & 0.846 & 1.000 & 1.222 & 1.571 & 2.200 & 3.667 & 11.000 & 55 \\
\hline 6 & 0.474 & 0.529 & 0.600 & 0.692 & 0.818 & 1.000 & 1.286 & 1.800 & 3.000 & 9.000 & 45 \\
\hline 7 & 0.368 & 0.412 & 0.467 & 0.538 & 0.636 & 0.778 & 1.000 & 1.400 & 2.333 & 7.000 & 35 \\
\hline 8 & 0.263 & 0.294 & 0.333 & 0.385 & 0.455 & 0.556 & 0.714 & 1.000 & 1.667 & 5.000 & 25 \\
\hline 9 & 0.158 & 0.176 & 0.200 & 0.231 & 0.273 & 0.333 & 0.429 & 0.600 & 1.000 & 3.000 & 15 \\
\hline 10 & 0.053 & 0.059 & 0.067 & 0.077 & 0.091 & 0.111 & 0.143 & 0.200 & 0.333 & 1.000 & 5 \\
\hline Average & 95 & 85 & 75 & 65 & 55 & 45 & 35 & 25 & 15 & 5 & \\
\hline
\end{tabular}

Source: [19]

Recently, [9] suggested that the equalizing coefficients be calculated as ratios of the detailed LPE (DLPE), determined after [16]. They also adapted FAO Quantitative Land Capability Classification in [17] to the National Land Categorization scheme in order to facilitate implementation of land consolidation activities in the country. The advantage of FAO Quantitative Land Suitability Classification is that, apart from the natural conditions of production, it also takes into account a number of production factors: the specific type of land use; economic and social conditions; opportunities for land protection from degradation; current economic results - income and profit. After the adaptation, [12] recommend two FAO groups for land consolidation activities: (S1) highly suitable and (S2) moderately suitable (Tab. 3) as appropriate for land consolidation activities.

Table 3. Adaptation of FAO Land Suitability Classification to the land categorization in Bulgaria

\begin{tabular}{||c|l|c|c||}
\hline \multicolumn{2}{||c|}{ Land Classes by FAO } & $\begin{array}{c}\text { DLPE } \\
\text { (marginal values) }\end{array}$ & Land consolidation group \\
\hline \hline $\mathrm{S}_{1}$ & Highly suitable land & $75-100$ & First \\
\hline $\mathrm{S}_{2}$ & Moderately suitable land & $50-75$ & Second \\
\hline $\mathrm{S}_{3}$ & Marginally suitable land & $35-50$ & Third \\
\hline $\mathrm{N}_{1}$ & Currently not suitable land & $20-35$ & \multirow{2}{*}{ Forth } \\
\hline $\mathrm{N}_{2}$ & Permanently not suitable land & $0-20$ & \\
\hline
\end{tabular}

Source: [12] 
According [12], this method avoids the errors connected with the coefficients' determination. By a numerical experiment in replacement of $3^{\text {rd }}$ to the $6^{\text {th }}$ category, the authors obtained a $13 \%$ bigger area by using DLPE rather than by using MLPE. They emphasize the fact that MLPE only gives one generalized solution for every two land categories, while DLPE gives a hundred solutions (10 × 10 DLPE) and the result for the owner will be fairer.

In this paper, the legal possibilities of both methods for carrying out an equivalent transformation under Art 88 paragraph 1 of [3] were established. A cross-tabulation, a regression analysis and an expert assessment helped the study. A combination of both methods was developed.

\section{Results and Discussion}

The 10\% limit imposed by Art 88, paragraph 1 of [3] permits only two types of exchange: 1) an exchange of areas only by adjacent categories; 2) an exchange of small areas of non-adjacent categories but also a big area of the same category so that the average result would be within the statutory limit. It determines a narrow range of applicable equalizing coefficients: from 0.9 to 1.1 (Tab. 4). The gray-colored cells in that table contain the coefficients that comply with the Law. The dark and light grey color show the values $=1.0$ and $<1.0$ respectively. It is seen that only $13 \%$ of all recommended coefficients work. The rounding of the coefficients to the first decimal place sums for 100 possible cases. The total number of cases for which Table 4 is representative is 10,000, illustrated in Table 5. It is seen that the Law has a $100 \%$ effect for exchange on the $1^{\text {st }}, 2^{\text {nd }}$ and the $3^{\text {rd }}$ land category whereby equalization and exchange should be only between the adjacent categories. Equalization between the $3^{\text {rd }}$ and the $4^{\text {th }}$ category satisfies the Law only in one direction: from the $4^{\text {th }}$ towards the $3^{\text {rd }}$ category, the reverse is not true. This is an error that is due to the use of mean estimates (MLPE). The total number of permissible cases in Table 5 is 1500 , i.e. $15 \%$ of the total: 800 for the $1^{\text {st }}, 2^{\text {nd }}$ and $3^{\text {rd }}$ category $(53.33 \%$ of the permissible and $8.00 \%$ of the total cases); and 300 for the $4^{\text {th }}, 5^{\text {th }}$ and $6^{\text {th }}$ categories $(20.00 \%$ of the permissible and $3.00 \%$ of the total cases).

The method of the calculation of equalizing coefficients with DLPE [12] is presented in Figure 1 and Table 6. The total number of possible cases is also 10,000, while that of the permissible ones is 1,415, i.e. $14.15 \%$ : $670(67.00 \%$ of the permissible and $4.75 \%$ of the total cases) for the $1^{\text {st }}, 2^{\text {nd }}$ and $3^{\text {rd }}$ category and 745 for the rest of the categories. The advantage of this method (DLPE) is that the permissible cases of the $4^{\text {th }}, 5^{\text {th }}$ and $6^{\text {th }}$ categories are 499 (35.24\% of the permissible, $4.99 \%$ of the total cases). It is by $66.33 \%$ more compared to those of the traditional method (MLPE) and by $15.24 \%$ more considering the permissible cases per method. These results show that calculation with DLPE gives more opportunities for land exchange in $4^{\text {th }}, 5^{\text {th }}$ and $6^{\text {th }}$ category. These categories are most widespread in Bulgaria. 
Table 4. Equalizing coefficients, calculated on the basis of MLPE

\begin{tabular}{|c|c|c|c|c|c|c|c|c|c|c||}
\hline \multirow{2}{*}{ Soil category } & \multicolumn{10}{|c|}{ Soil category } \\
\cline { 2 - 12 } & 1 & 2 & 3 & 4 & 5 & 6 & 7 & 8 & 9 & 10 \\
\hline \hline 1 & 1.0 & 1.1 & 1.3 & 1.5 & 1.7 & 2.1 & 2.7 & 3.8 & 6.3 & 19.0 \\
\hline 2 & 0.9 & 1.0 & 1.1 & 1.3 & 1.5 & 1.9 & 2.4 & 3.4 & 5.7 & 17.0 \\
\hline 3 & 0.8 & 0.9 & 1.0 & 1.2 & 1.4 & 1.7 & 2.1 & 3.0 & 5.0 & 15.0 \\
\hline 4 & 0.7 & 0.8 & 0.9 & 1.0 & 1.2 & 1.4 & 1.9 & 2.6 & 4.3 & 13.0 \\
\hline 5 & 0.6 & 0.6 & 0.7 & 0.8 & 1.0 & 1.2 & 1.6 & 2.2 & 3.7 & 11.0 \\
\hline 6 & 0.5 & 0.5 & 0.6 & 0.7 & 0.8 & 1.0 & 1.3 & 1.8 & 3.0 & 9.0 \\
\hline 7 & 0.4 & 0.4 & 0.5 & 0.5 & 0.6 & 0.8 & 1.0 & 1.4 & 2.3 & 7.0 \\
\hline 8 & 0.3 & 0.3 & 0.3 & 0.4 & 0.5 & 0.6 & 0.7 & 1.0 & 1.7 & 5.0 \\
\hline 9 & 0.2 & 0.2 & 0.2 & 0.2 & 0.3 & 0.3 & 0.4 & 0.6 & 1.0 & 3.0 \\
\hline 10 & 0.1 & 0.1 & 0.1 & 0.1 & 0.1 & 0.1 & 0.1 & 0.2 & 0.3 & 1.0 \\
\hline
\end{tabular}

Table 5. Number of cases where using MLPE satisfies the Law

\begin{tabular}{|c|c|c|c|c|c|c|c|c|c|c|}
\hline \multirow{2}{*}{ Land category } & \multicolumn{10}{|c|}{ Land category } \\
\hline & 1 & 2 & 3 & 4 & 5 & 6 & 7 & 8 & 9 & 10 \\
\hline 1 & 100 & 100 & & & & & & & & \\
\hline 2 & 100 & 100 & 100 & & & & & & & \\
\hline 3 & & 100 & 100 & & & & & & & \\
\hline 4 & & & 100 & 100 & & & & & & \\
\hline 5 & & & & & 100 & & & & & \\
\hline 6 & & & & & & 100 & & & & \\
\hline 7 & & & & & & & 100 & & & \\
\hline 8 & & & & & & & & 100 & & \\
\hline 9 & & & & & & & & & 100 & \\
\hline 10 & & & & & & & & & & 100 \\
\hline
\end{tabular}

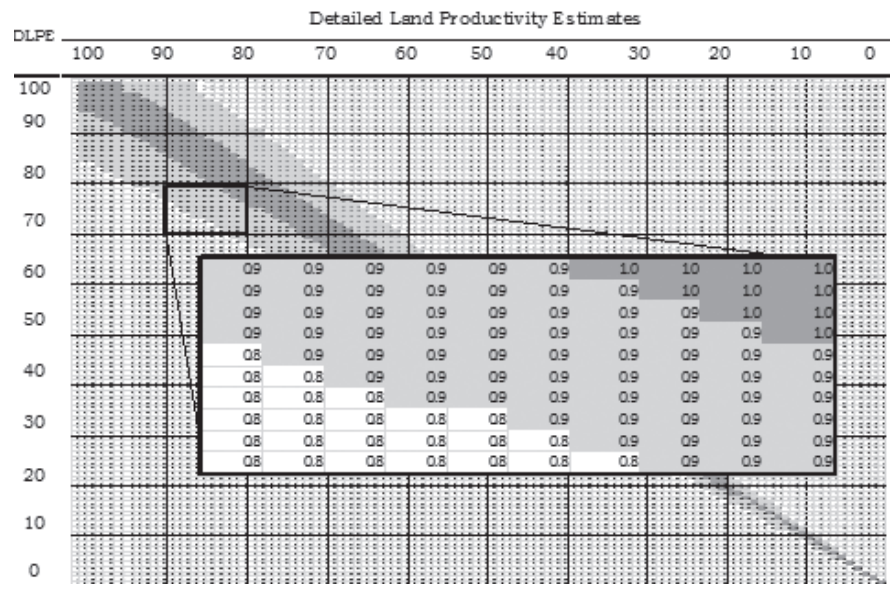

Fig. 1. Equalizing coefficients, calculated on the basis of DLPE 
Table 6. Number of cases when the use of DLPE satisfies the Law

\begin{tabular}{|c|c|c|c|c|c|c|c|c|c|c|c|}
\hline \multirow{2}{*}{ Land category } & \multicolumn{10}{|c|}{ Land category } & \\
\hline & 1 & 2 & 3 & 4 & 5 & 6 & 7 & 8 & 9 & 10 & \\
\hline 1 & 100 & 73 & 2 & & & & & & & & 175 \\
\hline 2 & 86 & 100 & 61 & & & & & & & & 247 \\
\hline 3 & 7 & 76 & 100 & 49 & & & & & & & 232 \\
\hline 4 & & 3 & 62 & 100 & 33 & & & & & & 198 \\
\hline 5 & & & & 49 & 100 & 25 & & & & & 174 \\
\hline 6 & & & & & 31 & 91 & 15 & & & & 137 \\
\hline 7 & & & & & & 22 & 78 & 10 & & & 109 \\
\hline 8 & & & & & & & 12 & 62 & 3 & & 77 \\
\hline 9 & & & & & & & & 6 & 41 & 1 & 48 \\
\hline 10 & & & & & & & & & 1 & 17 & 18 \\
\hline Totally & 193 & 252 & 225 & 198 & 164 & 137 & 105 & 78 & 45 & 18 & 1415 \\
\hline
\end{tabular}

The number of permissible cases depends on land quality with coefficient of determination $R^{2}=0.94359$ (Fig. 2). The greatest share of permissible cases of the total: $1.91 \%$ is at DLPA $=87$. The main area of the permissible cases with a number of 971 $(68.62 \%$ of the total permissible) is at DLPA $=55-100$ (Tab. 7$)$.

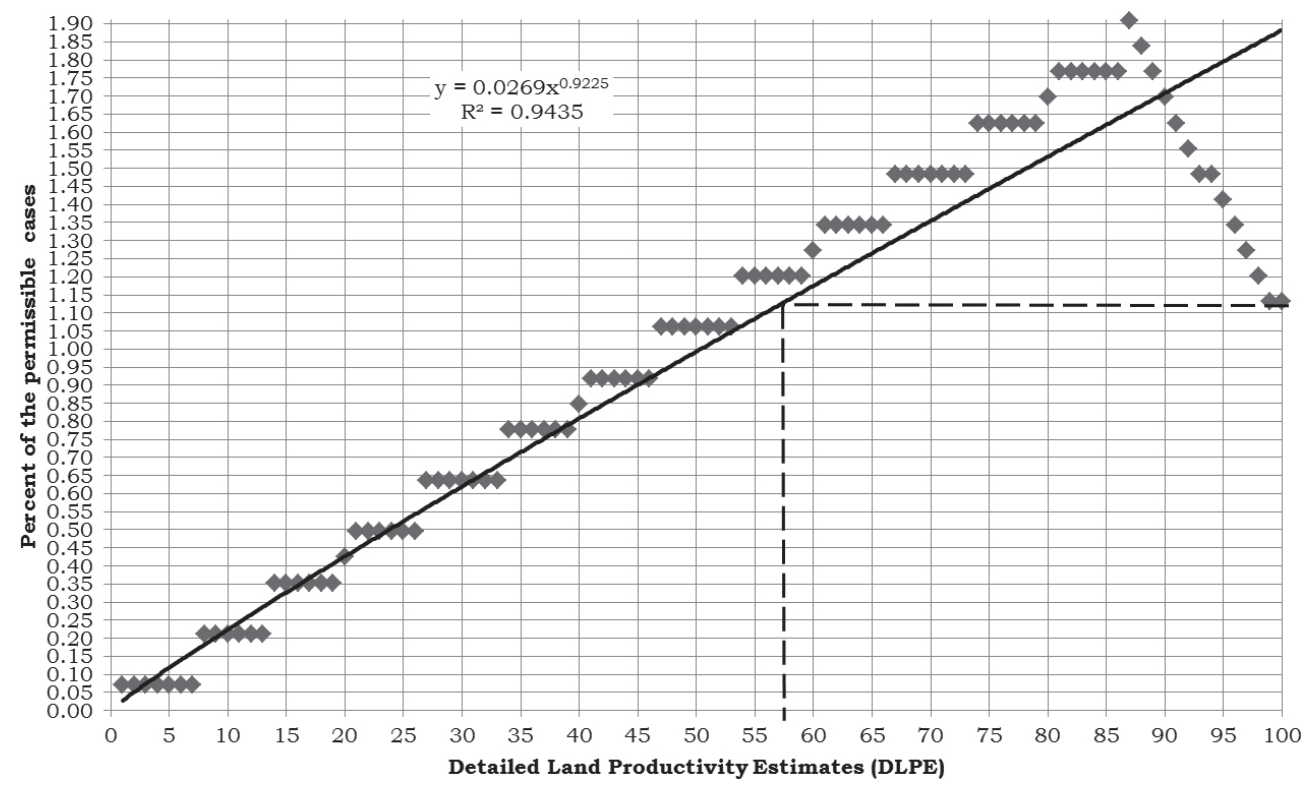

Fig. 2. Determining the range of DLPE that are suitable consolidation activities

It can be concluded from Figure 1 that the land consolidation activities that meet the normative requirement can be carried out on lands of the $1^{\text {st }}$ and $2^{\text {nd }}$ and category. A large number of statutory cases also occur in the lands of the $3^{\text {rd }}$ 
and $4^{\text {th }}$ category. These results are in compliance with the results of [12] according which the most suitable for land consolidation are the First and Second Land Consolidation Group with DLPE $=50-100$ (Tab. 2). The statutory eligibility for land exchange in the less-fertile lands is significantly reduced. Table 7 shows that when working with DLPE, the permissible cases in the $4^{\text {th }}$ and $5^{\text {th }}$ land categories significantly increase, at the expense of the cases of the $1^{\text {st }}, 2^{\text {nd }}$ and $3^{\text {rd }}$ land category.

Table 7. Number of permissible cases meeting the legal conditions in comparison to the two methods for equalizing land by group of land categories and land consolidation groups

\begin{tabular}{||l|c|c|c|c|c|c||}
\hline \multicolumn{1}{|c|}{ Method } & $\begin{array}{c}1-3 \text { land } \\
\text { category } \\
\left(1^{\text {st }} \text { LC group }\right)\end{array}$ & $\begin{array}{c}4-5 \text { land } \\
\text { category } \\
\left(2^{\text {nd }} \text { LC group }\right)\end{array}$ & $\begin{array}{c}\text { Totally: } \\
1-5 \text { land } \\
\text { category }\end{array}$ & $\begin{array}{c}6-8 \text { land } \\
\text { category } \\
\left(3^{\text {rd }} \text { LC }\right. \\
\text { group })\end{array}$ & $\begin{array}{c}9-10 \text { land } \\
\text { category } \\
\left(3^{\text {rd }} \text { LC }\right. \\
\text { group })\end{array}$ & Totally \\
\hline Based on MLPE & 800 & 200 & 1,000 & 300 & 200 & 1,500 \\
\hline Based on DLPE & 670 & 362 & 1,032 & 320 & 63 & 1,415 \\
\hline $\begin{array}{l}\text { Combination } \\
\text { of both } \\
\text { methods }\end{array}$ & 800 & 362 & 1,162 & 320 & 200 & 1,684 \\
\hline
\end{tabular}

Given these results, the following can be suggested, which will result in increasing the number of permissible cases:

1 ) The equalizing coefficients for the $1^{\text {st }}, 2^{\text {nd }}, 3^{\text {rd }}, 9^{\text {th }}$ and $10^{\text {th }}$ land category to be calculated by using MLPE. This is to increase the possibilities for land consolidation implementation. When considering the interests of owners, it is better to use DLPE.

2) The equalizing coefficients for the $4^{\text {th }}, 5^{\text {th }}, 6^{\text {th }}, 7^{\text {th }}$ and $8^{\text {th }}$ land category to be calculated by using DLPE.

By using this methodology, 1,684 cases will be permissible for land consolidation activities. They will increase with $12.20 \%$ and $18.94 \%$ compared to the traditional method [16] and the method of [12], respectively. The permissible cases for the lands of $1^{\text {st }}, 2^{\text {nd }}$ and $3^{\text {rd }}$ category will be 800 ; for those of $4^{\text {th }}$ and $5^{\text {th }}$ category -362 ; for $6^{\text {th }}, 7^{\text {th }}$ and $8^{\text {th }}$ category -320 ; and for $9^{\text {th }}$ and $10^{\text {th }}$ category -200 .

From what has been said so far, it is clear that the Law is too restrictive to the possibilities for carrying out land consolidation activities. We believe that Art. 88, paragraph 1 of [3] must be amended to allow the transformation of ownership into non-adjacent categories and into a larger range of categories. Also, it is necessary to delineate appropriate zones for land consolidation in the agricultural territory of Bulgaria. Further, to elaborate a flexible technology to equate areas in these zones according to their natural and production characteristics. 
To develop land consolidation plans (Figs. 3 and 4) a large amount of information has to be processed. GIS are appropriate for the delineation of the appropriate zones and make the redistribution of the properties according to the required criteria.

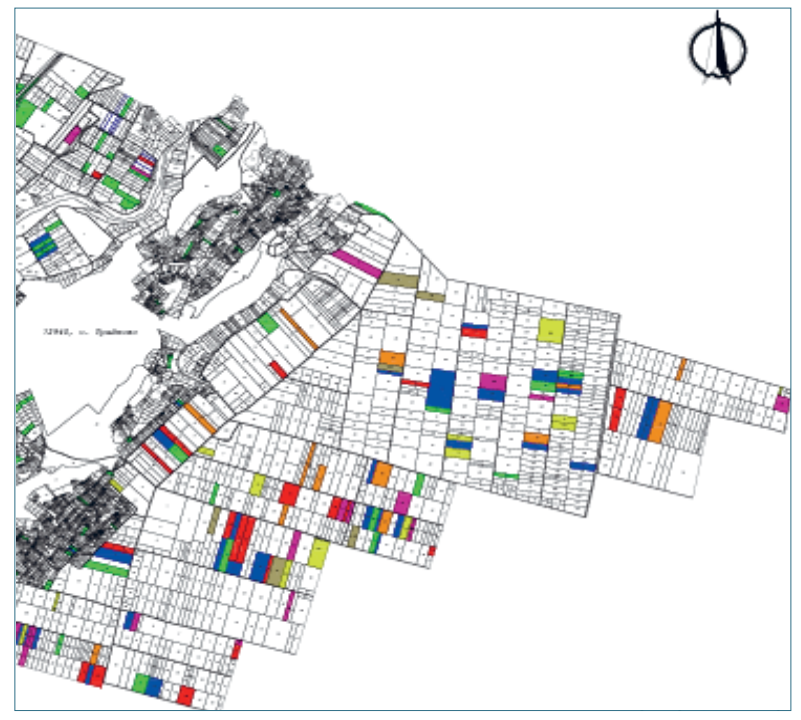

Fig. 3. A map of landed properties in the village of Traykovo, Lom Region, Bulgaria before land consolidation

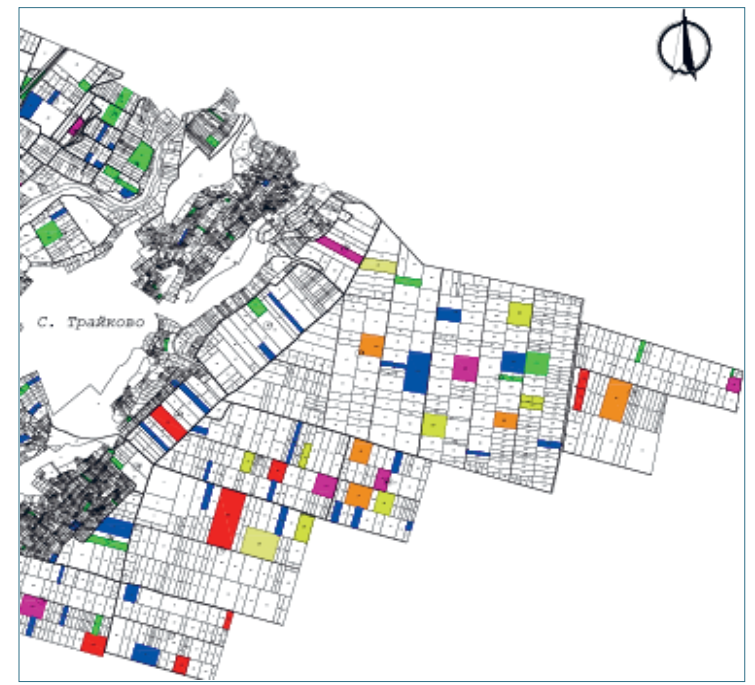

Fig. 4. A map of landed properties in the village of Traykovo, Lom Region, Bulgaria after land consolidation 
The following general types of data have to be collected and processed:

1) data identifying the land owners included in the land consolidation plan: name, ID number, desirable location and scale of consolidation;

2) property data before land consolidation: data of the settlement's land, contour, location, title, unique ID number, cadastral module, soil type, land category, slope, area, ownership documents, method of use;

3) data on the newly formed properties and their owners: analogous to (1) and (2) information;

4) data for equalization of differences in the area and value of the properties before and after the consolidation.

\section{Conclusions}

The implementation of a contemporary methodology for the equalization of categories using Mean Land Productivity Estimates is restricted to land consolidation by Art. 88, paragraph 1 of [3] in 15\% of all possibilities. It generally permits equating land only between adjacent categories from the $1^{\text {st }}$ to the $3^{\text {th }}$ category. It is possible to extend its implementation within the $5^{\text {th }}$ to the $8^{\text {th }}$ land category by the Detailed Land Productivity Estimates. This would increase land consolidation implementation by $12-18 \%$.

In agricultural territories, zones should be determined and delineated which are suitable for land consolidation, based on the adapted FAO Land Suitability Classification and a flexible methodology for land exchange should also be developed, one which considers the natural and productive characteristics of the site.

Legislation needs improvement in order to extend the possibilities of land consolidation implementation to larger areas and land categories.

\section{References}

[1] Cadaster and Land Consolidation Act. Prom. 1941, denom. 1950.

[2] Agricultural Land Ownership and Use Act. Prom. SG No. 17 of 1 Mar 1991, last am. SG No. 61 of 2 Aug 2019.

[3] Implementing Regulations of Agricultural Land Ownership and Use Act. Prom. SG 34 of 30 Apr 1991, last am. and suppl. SG, 100 of 20 Dec 2019.

[4] Sklenicka P., Janovska V., Salek M., Vlasak J., Molnarova K.: The Farmland Rental Paradox: Extreme land ownership fragmentation as a new form of land degradation. Land Use Policy, vol. 38, 2014, pp. 587-593.

[5] Cegielska K., Noszczyk T., Kukulska A., Szylar M., Hernik J., Dixon-Gough R., Jombach S., Valanszki I., Kovacs K.F.: Land use and land cover changes in post-socialist countries: Some observations from Hungary and Poland. Land Use Policy, vol. 78, 2018, pp. 1-18. 
[6] Janus J., Taszakowski J.: Spatial differentiation of indicators presenting selected barriers in the productivity of agricultural areas: A regional approach to setting land consolidation priorities. Ecological Indicators, vol. 93, 2018, pp. 718-729. https://doi.org/10.1016/j.ecolind.2018.05.050.

[7] Noga K., Balawejder M., Matkowska K.: Dimensions of the destruction of road network providing access to cadastral parcels resulting from the motorway construction. Geomatics and Environmental Engineering, vol. 11, no. 4, 2017, pp. 65-81.

[8] Stręk Ż., Noga K.: Method of Delimiting the Spatial Structure of Villages for the Purposes of Land Consolidation and Exchange. Remote Sensing, vol. 11 (11), 2019, 1268. https://doi.org/10.3390/rs11111268.

[9] Cay T., Ayten T., Iscan F.: Effects of different land reallocation models on the success of land consolidation projects: Social and economic approaches. Land Use Policy, vol. 27, issue 2, 2010, pp. 262-269. https://doi.org/10.1016/j.landusepol.2009.03.001.

[10] Stańczuk-Gałwiaczek M., Sobolewska-Mikulska K., Ritzema H., van Loon-Steensma Jantsje M.: Integration of water management and land consolidation in rural areas to adapt to climate change: Experiences from Poland and the Netherlands. Land Use Policy, vol. 77, 2018, pp. 498-511. https://doi.org/10.1016/ j.landusepol.2018.06.005.

[11] Antova G., Kunchev I., Mickrenska-Cherneva C.: Point clouds in BIM. IOP Conference Series: Earth and Environmental Science, vol. 44, issue 4, 042034, 2016. https://doi.org/10.1088/1755-1315/44/4/042034.

[12] Георгиев Б., Банов М., Трифонова Т., Кръстева-Пенкова В., Митрева 3., Колчаков В., Ненов М., Митева Н.: Съвременни научни постановки за възстановяване, подььржане кадастьра на земеделските земи и агроекологични похвати при осъществяване на комасационни активности. Научен Проект ПОЗМ 173, Селскостопанска академия, София 2016 [Georgiev B., Banov M., Trifonova T., Krasteva-Penkova V., Mitreva Z., Kolchakov V., Nenov M., Miteva N.: Savremenni nauchni postanovki za vazstanovyavane, poddarzhane kadastara na zemedelskite zemii agroekol. Nauchen Proekt POZM 173, Selskostopanska akademia, Sofia 2016].

[13] Митрева 3., Любенова И., Панков В., Радованова И., Георгиев Б.: Качествена съпоставимост, взаимозаменяемост, агроекологична база за комасаизионни активности и пазарни цени на земеделските земи. [in:] Агроекологичен потенциал на поземлените имоти в землище Ореш и научна база за рацииолино земеползване, НТС на специалистите в земеделието, София 2017, pp. 109-116 [Mitreva Z., Lyubenova I., Pankov V., Radovanova I., Georgiev B.: Kachestvena sapostavimost, vzaimozamenyaemost, agroekologichna baza za komasatsionni aktionosti i pazarni tseni na zemedelskite zemi. [in:] Agroekologichen potentsial na pozemlenite imoti $v$ zemlishte Oresh i nauchna baza za ratsionalno zemepolzvane, NTS na spetsialistite v zemedelieto, Sofia 2017]. 
[14] Павлов П.: Географски информационни системи - приложение в развитието и управлението на големи населени места. Геодезия, картография, земеустройство, XXXIX, 4, pp. 16-20 [Pavlov P.: Geografski informatsionni sistemi prilozhenie $v$ razvitieto i upravlenieto na golemi naseleni mesta. Geodezia, kartografia, zemeustroystvo, XXXIX, 4, 1999, pp. 16-20].

[15] Пенев П.Т., Микренска-Чернева К.: Спецุиализирано картографиране в България. Интел Ентранс, София 2015 [Penev P.T., Mikrenska-Cherneva K.: Spetsializirano kartografirane v Bulgaria. Intel Entrans, Sofia 2015].

[16] Петров Е., Кабакчиев И., Божинова П., Стоева А., Георгиева Я., Хершкович Е., Дилков Д.: Методика за работа по кадастьра на селскостопанските земи в НРБ. Асоциация НА. ПС, София 1988 [Petrov E., Kabakchiev I., Bozhinova P., Stoeva A., Georgieva Ya., Hershkovich E., Dilkov D.: Metodika za rabota po kadastara na selskostopanskitezemi v NRB. Asotsiatsia NA. PS, Sofia 1988].

[17] FAO: A framework for land evaluation. Soils Bulletin, 32, FAO and Agriculture Organization of the United Nations, Rome 1976.

[18] Ordinance on the Categorization of Agricultural Lands at the Change of their Permanent Purpose of Use. Prom SG 90 of 24 Oct 1996, last amend and suppl. SG 93 of 9 Nov 2018.

[19] Бюлетин № 6. Министерство на Селскостопанското развитие, земеползването и възстановяването на поземлената собственост, Управление Поземлена реформа, 1994 [Вyuletin № 6. Ministerstvo na Selskostopanskoto razvitie, zemepolzvaneto i vazstanovyavaneto na pozemlenata sobstvenost, Upravlenie Pozemlena reforma, 1994].

\section{Warunki prawne i zasady wymiany nieruchomości gruntowych w procesie scalania oraz określania rekompensat za grunty objęte scaleniem w Bułgarii}

Streszczenie: Scalenie i wymiana gruntów wymagają określenia wartości szacunkowej gruntów wymienianych lub scalanych obszarów. Poważnym niedociągnięciem $\mathrm{w}$ przepisach dotyczących scalania gruntów, określonych $\mathrm{w}$ ustawie o własności i użytkowaniu gruntów rolnych z 1991 roku, jest dopuszczalna 10-procentowa różnica między określanymi wartościami szacunkowymi przed scaleniem i po scalaniu gruntów. Stosowana obecnie metodyka porównywania gruntów na podstawie ich jakości i ograniczenia wynikające z ustawy powodują że scalaniu podlegają tylko grunty wysoko produktywne od I do III klasy. Celem niniejszego opracowania jest zaproponowanie poszerzenia zakresu metody scalania gruntów na większych obszarach oraz zarekomendowanie sprawiedliwszej metody obliczeń przy porównywaniu gruntów według ich jakości. W tym celu połączono dwa podejścia. Jedno z nich opiera 
się na średnich szacunkach produktywności gruntów na podstawie Bułgarskiego Systemu Klasyfikacji Gruntów, drugie - na szczegółowych szacunkach produktywności gruntów dla każdej kategorii gruntów. Zaproponowano określenie obszarów nadających się do scalania za pomocą odpowiednio dostosowanej klasyfikacji przydatności gruntów. Zastosowano analizę regresji i ocenę ekspercką. Określono i usystematyzowano dane wymagane do przetwarzania danych w systemie GIS. Przedstawiono propozycję udoskonalenia ram prawnych.

\section{Słowa}

kluczowe: scalanie gruntów, prawodawstwo, jakość gruntów, współczynniki wyrównawcze, GIS 